\title{
Using Double Pressure Heat Recovery Steam Generator Equipped with Duct Burner for Full Repowering a Steam Power Plant and Its Analysis by Exergy Method
}

\author{
V. Rohani and M. Ahmadi
}

\begin{abstract}
Repowering is defined as adding gas turbine unit(s) to steam cycle and using exhaust gases to increase cycle efficiency. Repowering methods are divided into two main ways: full repowering and partial repowering. In this research Be'sat steam power plant in Tehran has been considered as reference steam power plant. This old power plant has been designed by General Electric Corporation with $\mathbf{3 1 . 4 6 \%}$ efficiency, whereas its current efficiency is $\mathbf{2 6 . 8 1 \%}$. In this research by using full repowering a combined cycle have been designed with double pressure heat recovery steam generator equipped with duct burner and through exergy analysis, the functional parameters of the repowered cycle has been studied in the two states of no duct burner and various modes with duct burner (in terms of the fuel flow feed to duct burner). The results showed that thermal and exergy efficiencies for repowered cycle at without duct burner state are $44.39 \%, 43.06 \%$ respectively and in other states of using burner in general state thermal and exergy efficiencies are higher than reference cycle. It has been shown by results that in repowered cycle combustion chamber in the gas section and HRSG in the steam section have the highest exergy losses. Also The results showed that by using duct burner and increasing the feed fuel, in general state thermal and exergy efficiencies of repowered cycle, decrease and the temperature of the exhaust gas from stack and the exergy losses by it, the generated steam flow and the generation power increases.
\end{abstract}

Index Terms-Efficiency, exergy analysis, full repowering, heat recovery steam generator.

\section{INTRODUCTION}

Nowadays energy as one of the most significant issues of human daily life plays remarkable role in all aspects of life. In between power plants generating electricity are major sources of energy generation. Among power plants generating electricity, combined cycle power plants in comparison to gas and steam power plants individually have greater efficiencies; because both sources of generating power are used in the combined cycle power plants. In this research it has been tried to obtain a new combined cycle using full repowering method by considering the design restrictions and efforts have been made to study its weaknesses and strengths by using exergy analysis. Also the effects of various functional states of duct burner on repowered cycle functional parameters such as thermal

Manuscript received November 22, 2013; revised March 20, 2014.

Vahid Rohani is with the Faculty of Mechanical Engineering, Shahid Rajaee Teacher Training University, Tehran, Iran (e-mail: vahidrohani67@yahoo.com).

Mostafa Ahmadi is with the Mechanics Department, Darol Fonoun Faculty, Bojnurd, Iran (e-mail: mostafa_ahmadi1976@yahoo.com). efficiency, the exergy efficiency of combined cycle, the exergy efficiency of HRSG... through exergy analysis are studied. Repowering includes utilization of exhaust gas of gas turbine(s) set to upgrade steam power plant performance. Repowering methods are classified into two main ways: full repowering and partial repowering.Full repowering is the most common way of repowering. In this method a HRSG and gas turbine(or turbines) are used instead of old boiler. This method is useful for power plants with minimum age of 25 years. Idea of using this this method has been suggested in 1949 for the first time and has been utilized in 1960 [1]. In full repowering various ways can be performed owing to the way considered to omit the feed water heater which include: Omit low pressure feed water heater, Omit low and high pressure feed water heater and not to omit feed water heaters. On the other hand, using additional combustion in HRSG has been widely developed for the purpose of controlling the temperature and the generated steam flow in the mode of lowering the load of gas turbine and/or offset the ambient changes. The burners that generate this additional combustion in boilers are called duct burners. One of the old steam power plants in Iran is Be'sat power plant. Its old age has been cuased an efficiency reduction since its operation time [2]. Modeling steam power plant cycles have been done according to the presented technical documents by General Electric Corporation. In this research after modeling steam turbines, their specifications have been considered in new concerning full repowering scenarios; feed water heaters have been omitted because of power plant old age. Design of HRSGs and gas turbine cycle has been done proportional to steam turbines in the reference cycle. Used HRSG is double pressure with reheat equipped with duct burner. Finally it has been tried to analyze functional parameters by exergy analysis. EES thermodynamic software has been used for modeling new cycle. In the past some researches have been conducted in the fields of repowering, exergy analysis of combined cycles and using duct burners. For example, Hosseinalipour S. M. et al. (2011) have done full repowering for a steam power plant; they have optimized economical and technical specifications of the new cycle [3]. Mehrpanahi A. et al. (2011) have investigated various methods of repowering on country electricity generating power plants to measure its effect on electricity generating costs [4]. Gambini M. and Guizzi G. L. (1989) have done full repowering for a steam power to reach higher ability of generating power [5]. In a similar research Brander J. A. and Chase D. L. (1992) have investigated practical restrictions of a steam cycle full repowering [6]. Using another method of repowering Mehrpanahi A. and Hoseinalipoor S. M. (2011) have 
optimized parallel feed water heat recovery for Shahid Rajaei power plant in Tehran to decrease electricity generating costs [7]. In another research Tajik Mansouri M. and Ahmadi P. (2012) have evaluated and compared three types of HRSG used in combined cycles to analyze effect of vapor pressure level enhancement in power and efficiency increase and reduction in combined cycles exergy destruction [8]. Bassily M. (2008) has been investigated power and efficiency enhancement using a HRSG triple pressure. They utilize duct burner and reheating to increase generating power [9]. Franco A. and Russo A. (2002) believed that by optimizing effective parameters on HRSG and using different HRSGs along with decreasing pinch temperature and increasing levels of heat absorption in the boiler, higher efficiency and power can be obtainable [10]. Backlund J. C. and Batshon $\mathrm{A}$. introduced the advantages and disadvantages of duct burner and studied using irregular fuels such as the gas produced from sewers, steel plants furnaces, decomposition of solid urban wastes...in the duct burner [11]. Dincer I. and Ahmadi P. designed a combined cycle equipped with duct burner and by using the genetic algorithm, optimized the target functions such as price of consumed fuel, production poor [12].

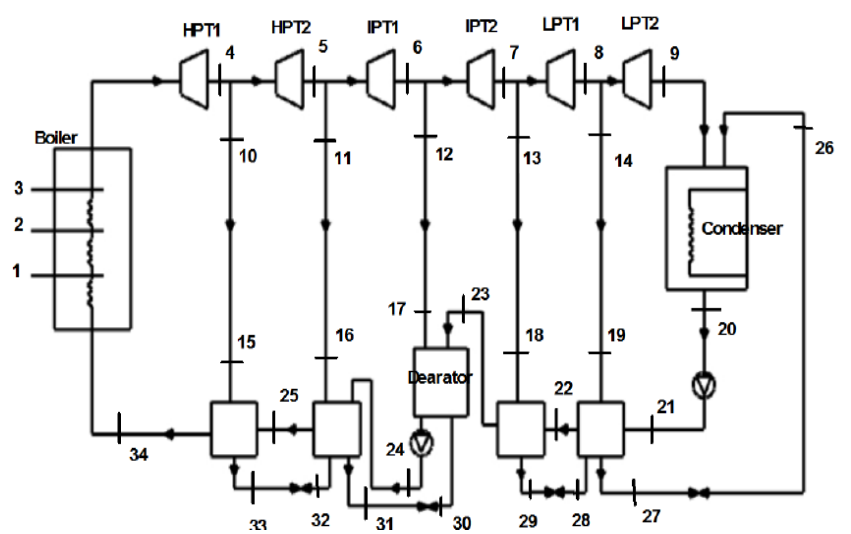

Fig. 1. Schematic diagram of a gas turbine cycle.

\section{REFERENCE CYCLE SPECIFICATIONS}

Be'sat power plant is an old steam power plant designed by General Electric corporation with $31.46 \%$ efficiency whereas its current real efficiency is $26.81 \%$. Efficiency reduction has been caused by power plant old lifetime and exhaustion [2]. A v94.2 gas turbine made by Simense Company with power of $160 \mathrm{MW}$ has been used in the gas section of the power plant. Steam cycle has a heat boiler, two high pressure turbines, two intermedial turbines and two low pressure turbines. Also a condenser and a set of feed water reheaters can be seen in this cycle. Part of steam turbines exhaust gas is extracted to the feed waters and reheats the boiler feed water. Fig. 1. Thermodynamic properties of steam/water in different parts of the reference cycle has been shown in Table I.

\section{REPOWERING OPERATION PROCEDURE}

1) Gas turbine and steam turbines have been considered exactly according to the reference cycle.

2) Size of used HRSG and gas turbine have been considered with regard to maximum arrival steam to the first high pressure turbine in the thermodynamic conditions of the reference cycle (turbine inlet pressure and temperature of the reference cycle) [3].

3 ) Restrictions of condenser in receiving the amount of steams fed by present cycle must be carefully considered. In designing the condenser, the amount of feeding stem flow is taken as $m_{\text {Cond }}=73.05 \mathrm{Kg} / \mathrm{S}$; however, this amount could be increased up to $45 \%$ [3].

4) Since power plant has a wet cooling tower condenser pressure usual range is 0.068 to 0.136 bar[13]. In this research condenser operational pressure which is equal to the condenser pressure in the reference cycle, is considered as a constant and equal to 0.72 bar.

5) A double pressure with reheat HRSG has been used in repowered cycle to utilize the exegy of exhaust gas of gas turbine set perfectly to produce steam.

\begin{tabular}{|c|c|c|c|c|c|}
\hline point & $\begin{array}{c}\text { Temperature } \\
(\mathrm{K})\end{array}$ & $\begin{array}{c}\text { Pressure } \\
\text { (bar) }\end{array}$ & $\begin{array}{c}\text { Entropy } \\
\left(\mathrm{KJ} / \mathrm{Kg}^{0} \mathrm{~K}\right)\end{array}$ & $\begin{array}{c}\text { Mass } \\
\text { Flow } \\
(\mathrm{Kg} / \mathrm{S})\end{array}$ & $\begin{array}{l}\text { Enthalpy } \\
(\mathrm{KJ} / \mathrm{Kg})\end{array}$ \\
\hline 1 & 581.7 & 96.61 & 3.334 & 91.94 & 1392.5 \\
\hline 2 & 578.0 & 91.78 & 5.665 & 91.94 & 2739.0 \\
\hline 3 & 783.1 & 87.20 & 6.708 & 91.94 & 3415.0 \\
\hline 4 & 663.0 & 33.60 & 6.826 & 84.58 & 3200.6 \\
\hline 5 & 580.4 & 17.23 & 6.873 & 78.58 & 3047.5 \\
\hline 6 & 476.7 & 6.50 & 6.941 & 73.05 & 2854.9 \\
\hline 7 & 392.8 & 1.68 & 7.211 & 68.09 & 2707.0 \\
\hline 8 & 365.6 & 0.77 & 7.090 & 62.67 & 2533.2 \\
\hline 9 & 315.8 & 0.08 & 7.321 & 62.67 & 2298.8 \\
\hline 10 & 663.0 & 33.60 & 6.826 & 7.36 & 3200.6 \\
\hline 11 & 580.4 & 17.23 & 6.873 & 6.00 & 3047.5 \\
\hline 12 & 476.7 & 6.50 & 6.941 & 5.33 & 2854.9 \\
\hline 13 & 403.0 & 2.68 & 7.001 & 4.96 & 2708.6 \\
\hline 14 & 365.6 & 0.77 & 7.090 & 5.42 & 2533.2 \\
\hline 15 & 635.7 & 31.26 & 6.766 & 7.36 & 3141.5 \\
\hline 16 & 558.9 & 16.02 & 6.825 & 6.00 & 3001.5 \\
\hline 17 & 466.5 & 6.05 & 6.930 & 5.33 & 2834.6 \\
\hline 18 & 400.6 & 2.50 & 6.897 & 4.96 & 2654.4 \\
\hline 19 & 365.6 & 0.72 & 6.979 & 5.42 & 2533.2 \\
\hline 20 & 316.2 & 0.72 & 0.612 & 73.05 & 180.0 \\
\hline 21 & 316.2 & 6.43 & 0.610 & 73.05 & 180.0 \\
\hline 22 & 358.3 & 6.24 & 1.132 & 73.05 & 355.9 \\
\hline 23 & 393.6 & 6.05 & 1.527 & 73.05 & 503.9 \\
\hline 24 & 435.3 & 108.08 & 1.952 & 91.94 & 690.8 \\
\hline 25 & 471.2 & 104.84 & 2.270 & 91.94 & 834.2 \\
\hline 26 & 315.8 & 0.08 & 0.727 & 10.38 & 216.4 \\
\hline 27 & 324.9 & 0.14 & 0.725 & 10.38 & 216.4 \\
\hline 28 & 363.3 & 0.71 & 1.250 & 4.96 & 398.0 \\
\hline 29 & 368.3 & 0.85 & 1.250 & 4.96 & 398.0 \\
\hline 30 & 432.4 & 6.05 & 2.061 & 13.36 & 726.9 \\
\hline 31 & 444.4 & 8.16 & 2.059 & 13.36 & 726.9 \\
\hline 32 & 455.6 & 16.02 & 2.330 & 7.36 & 852.4 \\
\hline 33 & 473.2 & 18.62 & 2.330 & 7.36 & 852.4 \\
\hline 34 & 508.2 & 101.69 & 2.641 & 91.94 & 1015.1 \\
\hline
\end{tabular}

6) The steam produced by HRSG should be able to change in accordance with the cycle conditions and the condenser limitations; for that reason, in studying the designed cycle, a value named $K$ has been used. This number is a coefficient for the steam flow that arrived into condenser and is in fact the amount of steam generated by boiler with respect to the performance conditions of duct burner and repowered cycle.

7) In repowered cycle, high pressure steam arrived into the first high pressure steam turbine and low pressure steam arrived into the intermedial pressure turbine. The discharging steam of the high pressure turbine entry into re-heater complex and after absorption of the heat once again at HRSG, it returns to the Intermedial turbines (Fig. 3).

8) Pressure generated by water pumps in the transfer pipelines will face some losses, so to approach real 
conditions some pressure losses are considered such as $3.5 \%$ in economizer pipes, $3 \%$ in superheater, $5 \%$ in reheater and $5.5 \%$ in water/steam pipes. There is no pressure loss in evaporator [14]. Also it should be mentioned that $5 \%$ of gas energy has been considered as energy losses related to the gas in the boiler [3].

9) In case of lower temperature of the gas discharge from boiler than the acid dew point of the gas mix, the water vapor content is distilled on the pre-heater and economizer pipes and in their compositions with other combustion products such as $\mathrm{CO} 2$, they produce corrosive acids that damages the pipes. In order to prevent this, in boilers design, the $\mathrm{T}=361^{\circ} \mathrm{K}$ is taken as the acid dew point of gas mixture to save the temperature of the gas that exit from boilers from lowering that point [8]-[12].

10) Natural gas is used as a fuel in both duct burner and gas turbine combustion chamber.

11) In repowered cycle, the keep pinch temperature difference not less than $10^{\circ} \mathrm{K}$; because if this temperature goes lower, we will need more heat transfer levels [15].

12) All processes are taken in steady state and steady flow.

\section{ENERGY ANALYSIS}

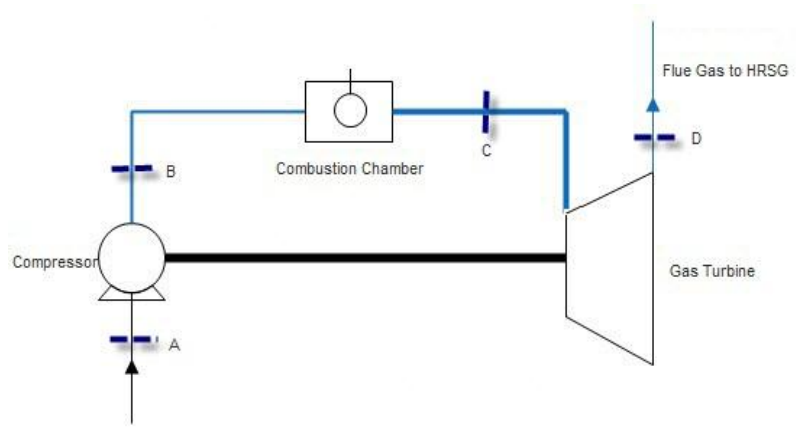

Fig. 2. Schematic diagram of a gas turbine cycle.

Energy balance has been used for control volume in steady state conditions to model cycles [9]. Set of gas turbines have been considered according to the simple brayton cycle as can be seen in Fig. 2.

\section{A. Air Compressor [8]}

$$
\begin{gathered}
T_{B}=T_{A}\left[1+\frac{1}{\eta_{A C}}\left(r_{c}^{\frac{\gamma_{a}-1}{\gamma_{a}}}-1\right)\right] \\
\dot{W}=\dot{m}_{a} \cdot C_{p, a}\left(T_{B}-T_{A}\right)
\end{gathered}
$$

$C_{p, a}$ has been defined as a function of temperature [12]:

$$
C_{p, a}(T)=1.04841-\left(\frac{3.8371 T}{10^{4}}\right)+\left(\frac{9.4537 T^{2}}{10^{7}}\right)-\left(\frac{5.49031 T^{3}}{10^{10}}\right)+\left(\frac{7.9298 T^{4}}{10^{14}}\right)
$$

\section{B. Combustion Chamber [9]}

$$
m_{a} h_{B}+\dot{m}_{f} L H V=\dot{m}_{g} h_{C}+\left(1-\eta_{A C}\right) \dot{m}_{f} L H V
$$

\section{Gas Turbine [2]}

$$
\begin{gathered}
\dot{W}_{G T}=\dot{m}_{g} C_{p, g}\left(T_{D}-T_{C}\right) \\
T_{D}=T_{C}\left[1-\eta_{G T}\left(1-\left(\frac{{ }_{C}}{P_{D}}\right) \frac{1-\gamma_{a}}{\gamma_{a}}\right)\right] \\
\dot{W}_{n e t}=\dot{W}_{G T}-\dot{W}_{A C}
\end{gathered}
$$

$$
\begin{gathered}
\dot{m}_{g}=\dot{m}_{f}+\dot{m}_{a} \\
\dot{m}_{a}=\frac{\dot{W}_{G T}}{(1+A F) C_{P, g}\left(T_{3}-T_{4}\right)-C_{P, g}\left(T_{2}-T_{1}\right)} \\
C_{p, g}(T)=0.991615-\left(\frac{6.99703 T}{10}\right)+\left(\frac{2.7129 T^{2}}{10^{7}}\right)-\left(\frac{1.22442 T^{3}}{10}\right)
\end{gathered}
$$

Constant values of gases in the products of combustion $0.2944 \mathrm{KJ} / \mathrm{Kg}^{0} \mathrm{~K}$, losses due to combustion chamber $3 \%$, low heat value of the fuel equals to methane heat value which is $50000 \mathrm{KJ} / \mathrm{Kg}$, combustion chamber efficiency has been considered $97 \%$, gas specific heat capacity and air used have been computed as a function of temperature.

\section{Duct Burner [12]}

Amount of the fuel fed to duct burner is taken as a variable and in order to prevent the overheating the super heater pipes, the amount of fed fuel should be less than $1 \mathrm{Kg} / \mathrm{S}$ [9].

$$
\begin{aligned}
& \dot{m}_{g} C_{p g}+\dot{m}_{f, D B} L H V=\dot{m}_{g, i n, H R S G} \cdot C_{p, g, i n, H R S G} T_{E}+ \\
& \left(1-\eta_{C C h, D B}\right) \dot{m}_{f, D B} L H V
\end{aligned}
$$

\section{E. HRSG}

In design of HRSG approach temperature difference have been considered $15^{\circ} \mathrm{K}$. Using energy equation for steam/water and gas in HRSG various sections following equations can be written [3]-[16]:

1) Steam/water

$$
\begin{gathered}
T_{g t, \text { out }, \text { pre }, \text { eva }}=T_{\text {pre }, \text { eva }}+\text { DELTA }{ }_{-} T_{p r e, p i n c h} \\
T_{g t, \text { out }, h p, \text { eva }}=T_{h p, \text { eva }}+\text { DELTA_ } T_{h p, p i n c h} \\
T_{g t, \text { out }, \text { lp }, \text { eva }}=T_{l p, \text { eva }}+\text { DELTA_ } T_{l p, p i n c h}
\end{gathered}
$$

2) Gas

$E$ to $F$

$$
\dot{m}_{g, \text { in }, H R S G} \cdot C_{p, g t} .\left(T_{E}-T_{F}\right)\left(1-E_{\text {Loss }}\right)=\dot{m}_{h p}\left(h_{12}-h_{11}+h_{16}-h_{15}\right)
$$

$F$ to $G$

$$
\dot{m}_{g, \text { in }, H R S G} \cdot C_{p, g t} \cdot\left(T_{F}-T_{G}\right)\left(1-E_{\text {Loss }}\right)=\dot{m}_{h p}\left(h_{11}-h_{10}\right)
$$

$G$ to $H$

$$
\dot{m}_{g, i n, H R S G} \cdot C_{p, g t} \cdot\left(T_{G}-T_{H}\right)\left(1-E_{\text {Loss }}\right)=\dot{m}_{h p}\left(h_{10}-h_{5}\right)+\dot{m}_{L p}\left(h_{7}-h_{5}\right)
$$

$H$ to $I$

$\dot{m}_{g, \text { in }, H R S G} . C_{p, g t} .\left(T_{H}-T_{I}\right)\left(1-E_{\text {Loss }}\right)=\left(\dot{m}_{h p}+\dot{m}_{L p}\right)\left(h_{5}-h_{4}\right)$

$I$ to $J$

$\dot{m}_{g, i n, H R S G} \cdot C_{p, g t} \cdot\left(T_{J}-T_{I}\right)\left(1-E_{\text {Loss }}\right)=\left(\dot{m}_{h p}+\dot{m}_{L p}\right)\left(h_{4}-h_{2}\right)$

$J$ to $k$

$\dot{m}_{g, \text { in }, H R S G} \cdot C_{p, g t} \cdot\left(T_{J}-T_{K}\right)\left(1-E_{\text {Loss }}\right)=\left(\dot{m}_{h p}+\dot{m}_{L p}\right)\left(h_{2}-h_{1}\right)$

The amount of emerged steam is defined as follows:

$$
\dot{m}_{\text {Steam }}=K \cdot \dot{m}_{\text {cond }}
$$

\section{F. Steam Turbine}

Power generated by steam turbines is as follows [3]:

$$
\dot{W}_{S T}=\Sigma_{\text {Stages }} \dot{m}_{S T, \text { in }}\left(h_{S T, \text { in }}-h_{S T, \text { out }}\right)
$$

thermal efficiency of the cycle is obtainable by following 
relation [3]:

$$
\eta_{C C}=\frac{\dot{W}_{G T}-\dot{W}_{A C}+\dot{W}_{\text {Steam }}}{\dot{Q}_{\text {in }, C C}}
$$

\section{EXERGY ANALYSIS}

Exergy analysis is defined on the basis of first and second laws of thermodynamic. Exergy analysis is a tool to analyze and determine system inefficiencies. Exergy is defined as follows [16]: If a system has $\mathrm{n}$ subset with temperature $\mathrm{T}$ and pressure $\mathrm{P}$ and also mole fractions as $y=1,2, \ldots, n$, exergy is defined as the maximum obtainable theoretical work in process from state $\left(P, T, Y_{i}\right)$ to dead state of $\left(P_{0}, T_{0}, Y_{i}\right)$.It should be mentioned that dead state $\left(P_{0}, T_{0}, Y_{i}\right)$ is a system state which there is perfect balance between system and its environment with temperature $T_{0}$ and pressure $P_{0}$ in this state is considered as the reference state. Exergy is divided into four sections (four kinds of exergy can be mentioned as): 1) physical exergy, 2) chemical exergy, 3) kinematic exergy, 4) potential exergy. In most exergy analysis just physical and chemical exergies are considered. In the current analysis kinematic and potential exergies have been ignored. Using first and second laws of thermodynamics, general exergy equation can be written as follows [10]-[16]:

$$
\dot{E}_{Q}+\sum \dot{m}_{i} e_{i}=\sum \dot{m}_{e} e_{e}+\dot{E}_{Q}+\dot{I}
$$

$e$ is unit exergy and $i$ is exergy losses.

$$
\begin{gathered}
\dot{E}_{Q}=\left(1-\frac{T_{0}}{T_{i}}\right) \dot{Q}_{i} \\
\dot{E}_{W}=\dot{W}
\end{gathered}
$$

Chemical and physical exergy of gas mixture:

$$
\begin{gathered}
e^{c h}=\left[\sum_{i=0}^{n} X_{i} e^{c h_{i}}+R T_{0} \sum_{i=0}^{n} X_{i} \operatorname{LnX} X_{i}+G^{E}\right] \\
E^{p h}=\left(h-h_{0}\right)-T_{0}\left(S-S_{0}\right)
\end{gathered}
$$

$G^{E}$ is related to the amount of Gibbs free energy which can be ignored in low pressures of the gas mixture.

0 index is used to show reference state and $T_{0}$ is the reference environment temperature [16]. Relation (29) and (30) are defined for fuel with $C_{X} H_{y}$ Composotions and fuel exergy respectively.

$$
\begin{gathered}
\xi=1.033+0.0169 \frac{y}{x}-\frac{0.0698}{x} \\
\xi=\frac{e_{f}}{L H V_{f}}
\end{gathered}
$$

Amount of fuel exergy is shown by $\dot{E}_{f}$. Combined cycle exergy and HRSG efficiencies are defined as follows [10]:

$$
\begin{gathered}
\eta_{C C}=\frac{\dot{W}_{G T}-\dot{W}_{A C}+\dot{W}_{\text {Steam }}}{\dot{E}_{f}} \\
\eta_{\text {ex }, \text { HRSG }}=\frac{\dot{E}_{\text {Steam }, \text { out }}-\dot{E}_{\text {water }, \text { in }}}{\dot{E}_{\text {flue }, \text { gas }, \text { in }}-\dot{E}_{\text {flue }, \text { gas }, \text { out }}}
\end{gathered}
$$

\section{REPOWERED CYCLE}

Using reference cycle and its related information a double pressure combined cycle are considered for full repowering. In these cycle natural gas has been used as fuel which its composition is presented in Table II [2]-[8].

TABLE II: VOLUME FRACTION OF THE NATURAL GAS COMPONENT

\begin{tabular}{|c|c|c|c|c|c|}
\hline Point & $\begin{array}{c}\text { Temperature } \\
(\mathrm{K})\end{array}$ & $\begin{array}{c}\text { Pressure } \\
\text { (bar) }\end{array}$ & $\begin{array}{c}\text { Mass } \\
\text { Flow } \\
(\mathrm{Kg} / \mathrm{S})\end{array}$ & $\begin{array}{c}\text { Specific } \\
\text { exergy } \\
(\mathrm{KJ} / \mathrm{Kg})\end{array}$ & $\begin{array}{c}\text { Exergy } \\
\text { (MW) }\end{array}$ \\
\hline A & 298.15 & 1.013 & 544.9 & 0 & 0 \\
\hline B & 733.2 & 16.19 & 544.9 & 417.3 & 227.3 \\
\hline $\mathrm{C}$ & 1353 & 15.71 & 555.4 & 1013.6 & 562.8 \\
\hline D & 793.2 & 1.013 & 555.4 & 235.2 & 130.6 \\
\hline
\end{tabular}

\begin{tabular}{lc}
\hline Component of natural gas & Volume fraction (\%) \\
\hline Methane & 98.57 \\
Ethane & 0.63 \\
Propane & 0.1 \\
Butane & 0.05 \\
Pentane & 0.04 \\
Nitrogen & 0.6 \\
Carbon dioxide & 0.01 \\
\hline
\end{tabular}

Used turbine specifications are presented in the Table III. Combustion chamber exhaust gas composition has been shown in Table IV [2].

\begin{tabular}{lcl}
\multicolumn{3}{l}{ TABLE III: SOME CHARACTERISTIC DATA OF GAS TURBINE } \\
\hline Parameter & Unit & Amount \\
\hline Fuel flow $(L H V)$ & MW & 50 \\
Pressure ratio & - & 15.98 \\
Gas turbine inlet temperature & K & 1353 \\
Gas turbine outlet temperature & K & 793.2 \\
Power output & MW & 160 \\
\hline
\end{tabular}

TABLE IV: Combustion PRoduct Mole Composition.

\begin{tabular}{lc}
\hline Component & Molar composition (\%) \\
\hline $\mathrm{N}_{2}$ & 74.463 \\
$\mathrm{O}_{2}$ & 12.623 \\
$\mathrm{CO}_{2}$ & 3.715 \\
$\mathrm{H}_{2} \mathrm{O}$ & 8.303 \\
$\mathrm{Ar}$ & 0.897 \\
\hline
\end{tabular}

Gas properties in different points of the repowered cycle are shown in Table $\mathrm{V}$.

Reference environment in this modeling is air with thermodynamic conditions of $P=1.013 \mathrm{bar}, T=298.15^{\circ} \mathrm{k}$ and its molar composition is presented in Table VI [17]. Basic and reference data to model combined cycle is listed according to the reference cycle properties in Table VII.

TABLE VI: REFERENCE ENVIRONMENT MODEL OF AIR

\begin{tabular}{lc}
\hline Air components & Molar fraction $(\%)$ \\
\hline $\mathrm{N}_{2}$ & 75.67 \\
$\mathrm{O}_{2}$ & 20.35 \\
$\mathrm{H}_{2} \mathrm{O}$ & 3.03 \\
$\mathrm{CO}_{2}$ & 0.0345 \\
$\mathrm{CO}$ & 0.0007 \\
$\mathrm{SO}_{2}$ & 0.0002 \\
$\mathrm{H}_{2}$ & 0.00005 \\
Others & 0.91455 \\
Others & 0.91455 \\
\hline
\end{tabular}

TABLE VII: INPUT DATA FOR THERMODYNAMIC MODELING OF THE

\begin{tabular}{ccc}
\multicolumn{3}{c}{ CYCLES } \\
\hline Parameter & Unit & Amount \\
\hline HP inlet temp. & $\mathrm{K}$ & 783.1 \\
HP inlet press & Bar & 87.21 \\
LP inlet temp. & $\mathrm{K}$ & $580^{(\mathrm{a})}$ \\
LP inlet press. & bar & 10.27 \\
Condenser press. & bar & 0.72 \\
a=Hot reheat temperature. & \\
\hline
\end{tabular}




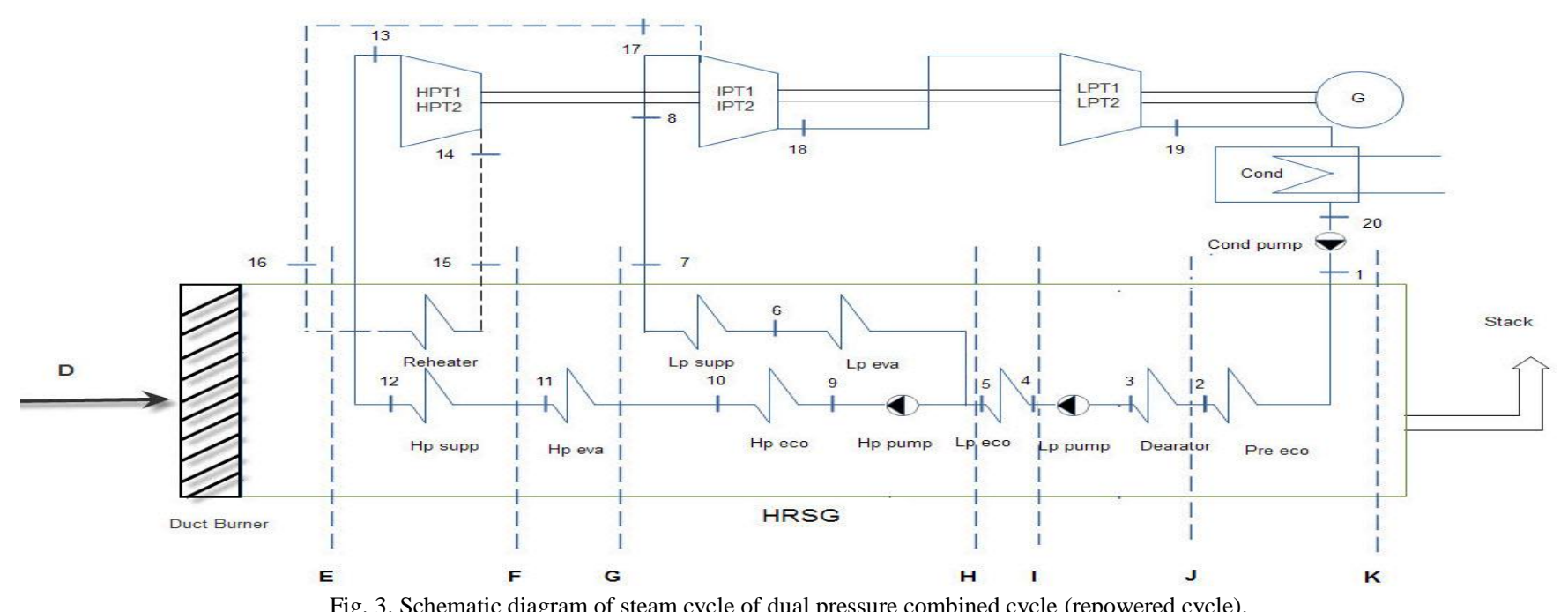

In fact steam turbines and condenser working conditions are determined with regard to the reference cycle. According to the Fig. 3 and by using above-mentioned thermodynamic relations (exergy and energy relations) the thermodynamic conditions of water/steam and gas in all points of the repowered cycle for both fired duct burner and unfired duct burner are studies. In fired mode the specific statue is considered as $\dot{m}_{f, D B}=0.5 \mathrm{Kg} / \mathrm{S}$. The coefficient $K$ for both with and without duct burner is taken as 1 and 1.093; respectively. The duct burner conditions might change with respect to the cycle demands in each time interval by changes in feeding fuel flow. For example, by increasing the flow of fuel fed to duct burner and increase in gas temperature, the amount of steam production increases. This is shown in the following tables and diagrams as the $K$ rises. Table $\mathrm{X}$ have listed the information on the performance of repowered cycle in different states of active duct burner. This table have shown only a few examples of states with suitable pinch temperature difference. For those reasons, the results of studying these tables could not be generalized to include all functional states.

\section{EXERGY ANALYSIS RESULTS}

In the current research exergy efficiency and exergy losses have been presented for every single parts of repowered cycle. Amount of heat absorption by HRSG components has been investigated and Thermal and exergy efficiencies of repowered cycle with turbines power generated by steam turbines have been evaluated. Also the effects of using duct burner on performance parameters of repowered cycle such as thermal efficiency of combined cycle, exergy efficiency of combined cycle, exergy efficiency of HRSG, exergy loss in exhausts, flow of produced steam and the production power of combined cycle are studied. Following figures based on a special state of duct burner which is $\dot{m}_{f, D B}=0$ and $K=1$.exregy losses of the combined cycle components has been shown in Fig. 4. Combustion chamber has the maximum loss of exergy in gas cycle set which is due to chemical reactions and great temperature difference between igniter and injecting fuel [2]. Also HRSG has the maximum exergy loss in the steam generation cycle. Considering HRSG result, designing a suitable HRSG to decrease gas exergy losses would be necessary. In fact amount and thermodynamic properties of generated steam are directly affected by configuration of HRSG components and its design. Amount of heat absorption related to the HRSG components has been shown in Fig. 5. It can be seen that maximum absorption occurs in HP evaporator and HP superheater. By the way in LP steam generating section, evaporator that its function is to generate steam, has the maximum amount of heat absorption. Because process of converting saturated water received from evaporator drum into saturated vapor exiting from evaporator pipes needs great amount of heat. Remarkable point is absorption of $3.977 \mathrm{MW}$ by reheater unit and $36.26 \mathrm{MW}$ by two components including preheater and deaerator. In fact this amount of heat absorption from gas can perfectly reveal the importance of adding surface of heat absorption to enhance level of exergy absorption. Heat related to the gas passing through space between pipes is used optimally .It should be noted that methods such as adding more level of heat absorption (for example reheater and pre heater feed water entering to the economizer), using pipes with fins, dividing economizer, evaporator and superheater levels, along the boiler, into multi sections would lead into added heat absorption and reduced heat losses due to exhaust gas of HRSG [18].

Amount of heat absorption gas and its temperature reduction would never continue to such an amount that leads to begin liquefying process of water vapor existing in the gas; because this would help forming corrosive acids which damage the pipes. In repowered cycle, temperature of exhausting gas from the stack (point $\mathrm{k}$ in the TABLE IX , $T=396.8$ ) is greater than dew point of gas mixture and this phenomena is prevented. According to Fig. 5 exergy losses from it is about $8.103 \mathrm{MW}$.

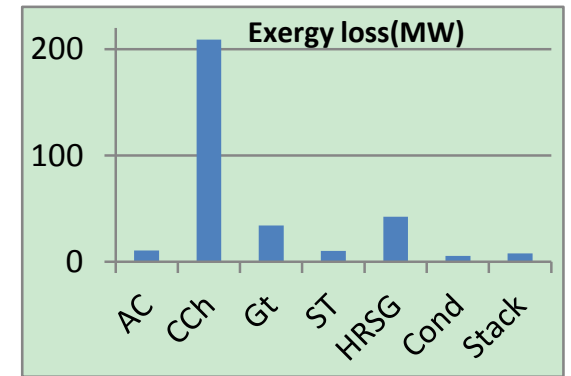

Fig. 4. Exergy losses for designed power plant component. 


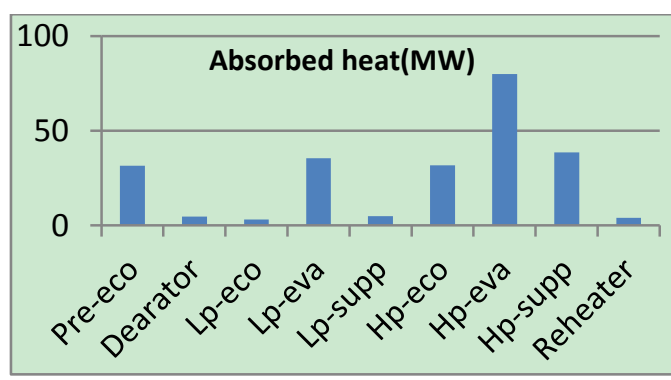

Fig. 5. Absorbed heat rate of HRSG components.

According to Fig. 6 in repowered cycle in the gas section, combustion chamber has the minimum level of exergy efficiency. In the steam generation section also condenser has the minimum efficiency and the first low pressure turbine has the maximum exergy efficiency. Remarkable point is greatness of the turbine efficiency in the gas cycle, while according to the Fig. 4 this component has significant exergy loss. This great efficiency is due to the remarkable amount of power generated by the gas turbine [2].

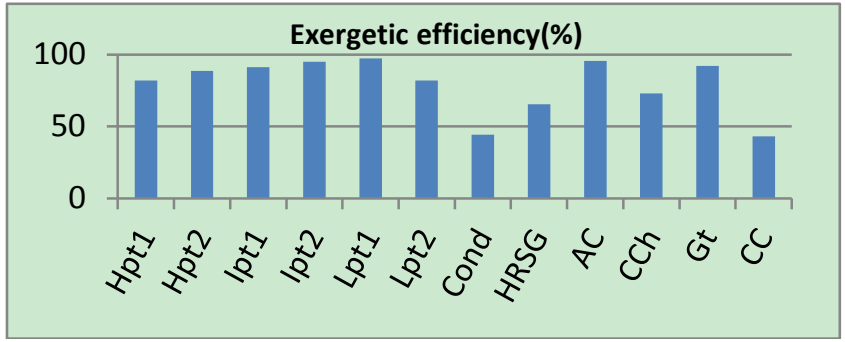

Fig. 6. Exergetic efficiency of the repowered cycle components.

TABLE VII: WATER/STEAM PROPERTIES IN FIRED AND UNFIRED CASES FOR REPOWERED CYCLE

\begin{tabular}{|c|c|c|c|c|c|c|c|c|c|c|}
\hline \multicolumn{6}{|c|}{ Unfired case load100\% $T_{a m b}=298.15^{\circ} \mathrm{K}$} & \multicolumn{5}{|c|}{ fired case $m_{f, D B}=0.5 \mathrm{Kg} / \mathrm{S} \quad$ load $100 \% T_{a m b}=298.15^{\circ} \mathrm{K}$} \\
\hline Point & $\begin{array}{c}\text { Temperature } \\
\text { (K) }\end{array}$ & $\begin{array}{c}\text { Pressure } \\
\text { (bar) }\end{array}$ & $\begin{array}{c}\text { Mass flow } \\
(\mathrm{Kg} / \mathrm{S})\end{array}$ & $\begin{array}{c}\text { Enthalpy } \\
(\mathrm{KJ} / \mathrm{Kg})\end{array}$ & $\begin{array}{l}\text { Exergy } \\
(\mathrm{MW})\end{array}$ & $\begin{array}{c}\text { Temperature } \\
\text { (K) }\end{array}$ & $\begin{array}{c}\text { Pressure } \\
\text { (bar) }\end{array}$ & $\begin{array}{c}\text { Mass flow } \\
(\mathrm{Kg} / \mathrm{S})\end{array}$ & $\begin{array}{l}\text { Enthalpy } \\
(\mathrm{KJ} / \mathrm{Kg})\end{array}$ & $\begin{array}{l}\text { Exergy } \\
\text { (MW) }\end{array}$ \\
\hline 1 & 316.2 & 6.43 & 73.05 & 180.9 & 0.20 & 316.2 & 6.43 & 79.84 & 180.9 & 0.22 \\
\hline 2 & 418.5 & 6.23 & 73.05 & 612.5 & 5.99 & 418.5 & 6.23 & 79.84 & 612.5 & 6.55 \\
\hline 3 & 433.5 & 6.23 & 73.05 & 677.3 & 7.41 & 433.5 & 6.23 & 79.84 & 677.3 & 8.10 \\
\hline 4 & 433.6 & 11.61 & 73.05 & 678.1 & 7.46 & 433.7 & 12.70 & 79.84 & 678.2 & 8.16 \\
\hline 5 & 443.3 & 11.27 & 73.05 & 720.2 & 8.44 & 447.3 & 12.31 & 79.84 & 737.2 & 9.70 \\
\hline 6 & 458.3 & 11.27 & 17.17 & 2782.0 & 14.34 & 462.3 & 12.31 & 18.76 & 2785.0 & 15.90 \\
\hline 7 & 584.1 & 10.87 & 17.17 & 3072.0 & 16.36 & 584.1 & 11.88 & 18.76 & 3069.0 & 18.08 \\
\hline 8 & 580.4 & 10.27 & 17.17 & 3065.0 & 16.18 & 580.4 & 11.23 & 18.76 & 3063.0 & 17.88 \\
\hline 9 & 445.0 & 98.59 & 55.88 & 732.3 & 7.04 & 449.0 & 98.59 & 61.08 & 749.8 & 8.06 \\
\hline 10 & 565.9 & 95.63 & 55.88 & 1302.0 & 20.09 & 565.9 & 95.63 & 61.08 & 1302.0 & 21.96 \\
\hline 11 & 580.9 & 95.63 & 55.88 & 2732.0 & 58.95 & 580.9 & 95.63 & 61.08 & 2732.0 & 64.43 \\
\hline 12 & 788.2 & 92.29 & 55.88 & 3422.0 & 79.96 & 788.2 & 92.29 & 61.08 & 3422.0 & 87.40 \\
\hline 13 & 783.1 & 87.21 & 55.88 & 3415.0 & 79.29 & 783.1 & 87.21 & 61.08 & 3415.0 & 86.67 \\
\hline 14 & 552.1 & 11.38 & 55.88 & 3001.0 & 51.73 & 557.8 & 12.44 & 61.08 & 3010.0 & 57.53 \\
\hline 15 & 552.1 & 11.38 & 55.88 & 3001.0 & 51.73 & 557.8 & 12.44 & 61.08 & 3010.0 & 57.53 \\
\hline 16 & 584.1 & 10.81 & 55.88 & 3072.0 & 53.24 & 584.1 & 11.82 & 61.08 & 3070.0 & 58.84 \\
\hline 17 & 580.4 & 10.27 & 73.05 & 3065.0 & 52.67 & 580.4 & 11.23 & 61.08 & 3063.0 & 58.22 \\
\hline 18 & 392.8 & 1.68 & 73.05 & 2730.0 & 42.74 & 392.8 & 11.83 & 79.84 & 2707.0 & 45.90 \\
\hline 19 & 318.7 & 0.09 & 73.05 & 2344.0 & 10.34 & 320.4 & 0.10 & 79.84 & 2366.0 & 12.31 \\
\hline 20 & 316.2 & 0.72 & 73.05 & 180.1 & 0.16 & 316.2 & 0.72 & 79.84 & 180.1 & 0.17 \\
\hline
\end{tabular}

TABLE IX: GAS Side PROPERTIES IN FIRED AND UNFIRED CASES FOR REPOWERED CyCle

\begin{tabular}{|c|c|c|c|c|c|c|c|c|c|c|}
\hline \multicolumn{6}{|c|}{ Unfired case load $100 \% T_{a m b}=298.15^{\circ} \mathrm{K}$} & \multicolumn{5}{|c|}{ fired case $m_{f, D B}=0.5 \mathrm{Kg} / \mathrm{S} \quad$ load $100 \% T_{a m b}=298.15^{\circ} \mathrm{K}$} \\
\hline point & $\begin{array}{l}\text { Temperature } \\
\text { (K) }\end{array}$ & $\begin{array}{l}\text { Pressure } \\
\text { (bar) }\end{array}$ & $\begin{array}{c}\text { Mass flow } \\
(\mathrm{Kg} / \mathrm{S})\end{array}$ & $\begin{array}{c}\text { Specific exergy } \\
(\mathrm{KJ} / \mathrm{Kg})\end{array}$ & $\begin{array}{l}\text { Exergy } \\
\text { (MW) }\end{array}$ & $\begin{array}{c}\text { Temperature } \\
\text { (K) }\end{array}$ & $\begin{array}{c}\text { Pressure } \\
\text { (bar) }\end{array}$ & $\begin{array}{c}\text { Mass flow } \\
(\mathrm{Kg} / \mathrm{S})\end{array}$ & $\begin{array}{c}\text { Specific exergy } \\
(\mathrm{KJ} / \mathrm{Kg})\end{array}$ & $\begin{array}{l}\text { Exergy } \\
\text { (MW) }\end{array}$ \\
\hline $\mathrm{E}$ & 793.2 & 1.013 & 555.4 & 235.20 & 130.6 & 823.6 & 1.013 & 555.9 & 259.90 & 144.47 \\
\hline $\mathrm{F}$ & 723.6 & 1.037 & 555.4 & 185.30 & 102.9 & 749.3 & 1.037 & 555.9 & 204.00 & 113.40 \\
\hline G & 586.0 & 1.028 & 555.4 & 96.69 & 53.7 & 599.6 & 1.028 & 555.9 & 104.40 & 58.35 \\
\hline $\mathrm{H}$ & 467.9 & 1.021 & 555.4 & 38.61 & 21.4 & 473.4 & 1.021 & 555.9 & 40.80 & 22.68 \\
\hline I & 462.5 & 1.018 & 555.4 & 36.21 & 20.1 & 465.0 & 1.018 & 555.9 & 37.19 & 20.67 \\
\hline $\mathrm{J}$ & 454.5 & 1.015 & 555.4 & 32.92 & 18.3 & 456.3 & 1.015 & 555.9 & 33.58 & 18.66 \\
\hline K & 398.6 & 1.013 & 555.4 & 14.63 & 8.1 & 395.2 & 1.013 & 555.9 & 13.74 & 7.63 \\
\hline
\end{tabular}

TABLE X: Repowered CyCle Operation Parameters with VARiable Duct Burner's Fuel

\begin{tabular}{|c|c|c|c|c|c|c|c|c|c|c|c|c|c|}
\hline State & $\dot{m}_{f . D B}$ & $K$ & $\dot{m}_{\text {steam }}$ & $\dot{W}_{C C}$ & $T_{i n, H R S G}$ & $T_{\text {out stack }}$ & $T_{H P, p i n c h}$ & $T_{l P, p i n c h}$ & $T_{\text {pre,pinch }}$ & $E_{\text {loss }, H R S G}$ & $E_{\text {loss,stack }}$ & $\eta_{T h, C C}$ & $\eta_{e x, C C}$ \\
\hline 1 & 0 & 1.000 & 73.05 & 234.2 & 793.2 & 398.6 & 5.12 & 9.62 & 21.00 & 42.42 & 8.103 & 0.4439 & 0.4306 \\
\hline 2 & 0.15 & 1.020 & 74.51 & 235.3 & 802.3 & 400.7 & 10.79 & 12.72 & 24.21 & 44.57 & 8.428 & 0.4396 & 0.4265 \\
\hline 3 & 0.25 & 1.047 & 76.48 & 236.6 & 808.4 & 396.7 & 11.81 & 10.10 & 21.71 & 45.79 & 7.828 & 0.4380 & 0.4249 \\
\hline 4 & 0.35 & 1.067 & 77.94 & 237.4 & 814.5 & 395.5 & 14.23 & 9.92 & 21.58 & 47.14 & 7.649 & 0.4355 & 0.4225 \\
\hline 5 & 0.50 & 1.093 & 79.84 & 238.3 & 823.6 & 395.2 & 18.67 & 11.06 & 22.76 & 49.26 & 7.615 & 0.4312 & 0.4184 \\
\hline 6 & 0.60 & 1.113 & 81.30 & 238.9 & 829.6 & 394.0 & 21.08 & 10.93 & 22.63 & 50.64 & 7.439 & 0.4284 & 0.4156 \\
\hline 7 & 0.70 & 1.133 & 82.77 & 239.3 & 835.7 & 392.7 & 23.50 & 10.84 & 22.51 & 52.03 & 7.265 & 0.4253 & 0.4126 \\
\hline 8 & 0.80 & 1.153 & 84.23 & 239.5 & 841.7 & 391.5 & 25.92 & 10.76 & 22.40 & 53.43 & 7.093 & 0.4220 & 0.4093 \\
\hline 9 & 0.90 & 1.173 & 85.69 & 215.3 & 847.6 & 390.3 & 28.34 & 10.71 & 22.28 & 54.84 & 6.923 & 0.3759 & 0.3647 \\
\hline 10 & 1.00 & 1.193 & 87.15 & 215.7 & 853.6 & 389.1 & 30.76 & 10.69 & 22.17 & 56.27 & 6.756 & 0.3734 & 0.3623 \\
\hline
\end{tabular}

Thermal and exergy efficiencies of repowered cycle in this case are $44.39 \%$ and $43.06 \%$, respectively. By using full repowering in this state $\left(\dot{m}_{f, D B}=0\right.$ and $\left.K=1\right)$ thermal efficiency in comparison to the reference cycle has been increased to the amount of $17.58 \%$. By using duct burner the thermal and exergy efficiencyes of repowered cycle decreases; because fuel consume for additional combustion, but in generation at all state of using duct burner, the thermal and exergy 
efficiencies of repowered cycle is greater than reference cycle (Fig. 8 \& Fig. 9). With respect to Table X. it could be seen that in combined cycle, by using duct burner, due to increase in the entrance gas temperature to HRSG, the amount of steam production increases. In steam turbines, this leads to increase in production power. On the other hand, the exergy increase of the gas from duct burner is absorbed by the HRSG and is spent to producing more steam. According to Fig.7. In each one of the performance states of duct burner, by increasing in amount of $K\left(K^{\prime}\right.$ as the determining factor for amount of produced steam), stack temperature decreases. This means absorbing more heat and better use of exergy by HRSG. In order to produce constant steam flow (same k), in different performance modes of duct burner, by increasing in the flow of fed fuel to the duct burner, the stack temperature increases and the exergy loss goes up; because, for producing this amount of steam, a specific amount of heat is needed and increase in heat and exergy in higher amount by duct burner, causes exit of heat and higher exergy by stack. For example, if the steam flow is $\dot{m}_{S T}=73.05 \mathrm{Kg} / \mathrm{S}(K=1)$ by dual pressure combined cycle, in the three states of $\dot{m}_{f \cdot D B}=0,0.8,1.6 \mathrm{Kg} / \mathrm{S}$, stack temperature will be $\mathrm{Tstack}=398.6,452.3,505{ }^{0} \mathrm{~K}$; respectively. In this cycle, by increasing in production steam flow, in each state of duct burner activation, for example $\dot{m}_{f, D B}=0.8 \mathrm{Kg} / \mathrm{S}$ due to increase in heat absorption from gas, the thermal efficiency of the combined cycle and the exergy efficiency of the combined cycle increase; on the other hand, for generating same steam flow in different performance states of duct burner,for example $K=1.05$ by increasing in the flow of fuel being fed to duct burner, those values decrease. Because the fuel consumption in duct burner is burned in Rankin cycle. The efficiency of Rankin cycle is less than combined cycle; as a result, the efficiency of combined cycle will decrease [15].

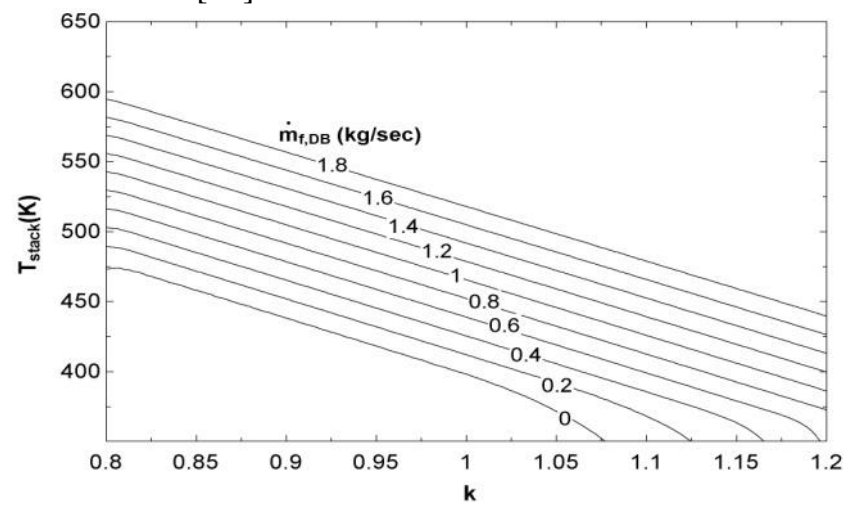

Fig. 7. Effects of the amount of fuel flow of duct burner and flow of produced steam on on HRSG outlet gas temperature.

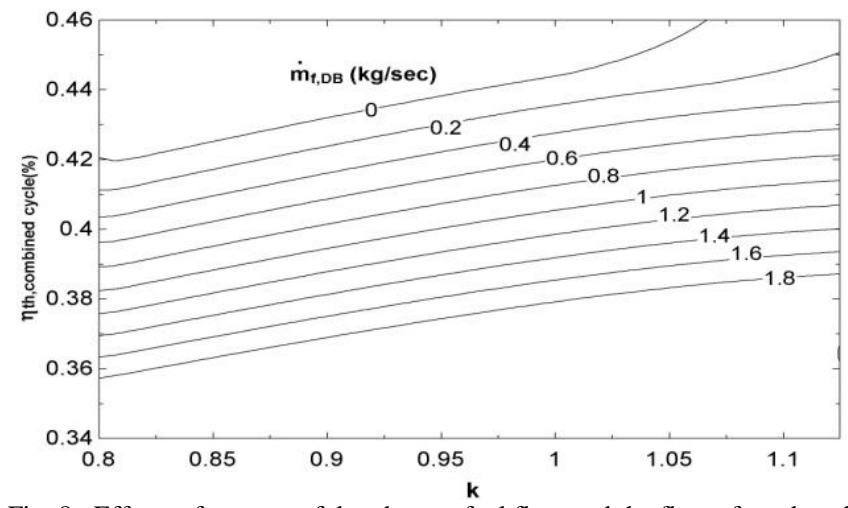

Fig. 8. Effects of amount of duct burner fuel flow and the flow of produced steam on the thermal efficiency of repowered cycle.

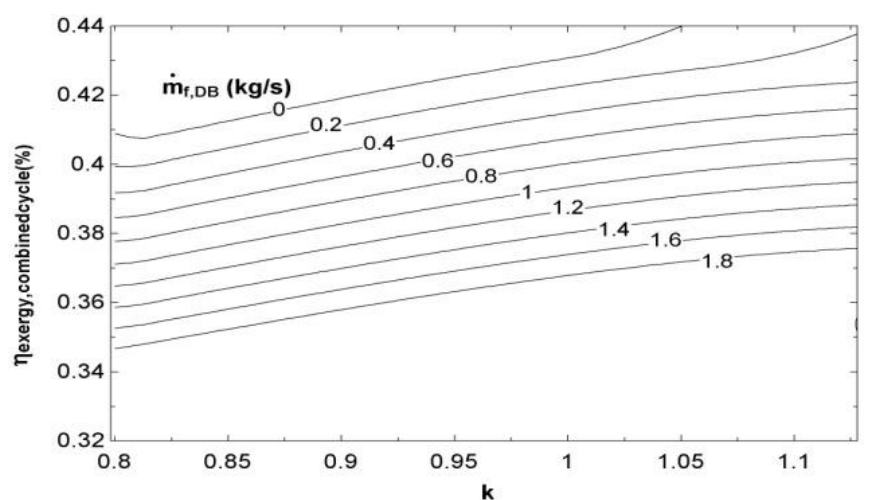

Fig. 9. Effects of amount of duct burner fuel flow and the flow of produced steam on the exergy efficiency of repowered cycle.

\section{CONCLUSION}

In this research full repowering operation of be'sat steam power plant has been designed using dual pressure HRSG to convert the reference cycle to a combined cycle and to enhance efficiency. Using this method thermal efficiency in repowered cycle increase For example for $\dot{m}_{f . D B}=0$ and $K=1$ state in comparison to the reference cycle it has been increased to the amount of $17.58 \%$. It is shown by repowered combined cycle exergy analysis that maximum exergy losses are related to combustion chamber and HRSG. Also by using duct burner and increase in flow of fuel fed to it the exergy and thermal efficiencies of repowered cycle decreases; while, the temperature of exiting gas from stack, the flow of produced steam and production power of the combined cycle increase.

\section{REFERENCES}

[1] H. Stoll, R. Smith, and L. Tomlinson, "Performance and economic considerations of repowering steam power plants," GE Company, 1994.

[2] M. Ameri, P. Ahmadi, and S. Khanmohammadi, "Exergy analysis of a 420 mw combined cycle power plant," International Journal of Energy Research, vol. 32, pp. 175-183, 2008.

[3] S. M. Hosseinalipour, A. Mehrpanahi, and K. Mobini, "Investigation of full repowering effects on techno-economic properties of a steam power plant," Iranian Modarres mechanic, 2011.

[4] A. Mehrpanahi, S. M. Hosseinalipour, and K. Mobini, "Investigation of the effects of repowering options on electricity generation cost on Iran steam plants," International Journal of Sustainable Energy, 2011.

[5] M. Gambini, and G. L. Guizzi, "Repowering of steam power plants for medium-high increase of power generated," in Proc. IEEE Energy Conversion Engineering Conference, 1989.

[6] J. A. Brandr and D. L. Chase, "Repowering application consideration," ASME Journal of Engineering for Gas Turbines and Power, vol. 114, pp. 643-652, 1992.

[7] S. M. Hosseinalipour and A. Mehrpanahi, "Optimization parallel feed water heat recovery for Shahid Rajaei power plant in Tehran to decrease electricity generating costs," Iranian Journal of Mechanical Engineering, 2011.

[8] M. T. Mansouri, P. Ahmadi, A. Ganjeh Kaviri, and M. N. Mohd Jaafar, "Exergetic and economic evaluation of the effect of HRSG configurations on the performance of combined cycle power plants," Energy Conversion and Management, vol. 58, pp. 47-58, 2012.

[9] A. M. Bassily, "Enhancing the efficiency and power of the triple-pressure reheat combined cycle by means of gas reheat, gas recuperation, and reduction of the irreversibility in the heat recovery steam generator," Applied Energy, vol. 85, pp. 1141-1162, 2008.

[10] A. Franco and A. Russo, "Combined cycle plant efficiency increase based on the optimization of the heat recovery steam generator operating parameters," International Journal of Thermal Sciences, vol. 41, pp. 843-859, 2002. 
[11] A. Batshon and J. C. Backlund, "Alternative fuel for supplementary firing add value and flexibility to combined cycle and cogeneration plants," International journal of Power Generation, 2001.

[12] P. Ahmadi and I. Dincer, "Thermodynamic analysis and thermoeconomic optimization of a dual pressure combined cycle power plant with a supplementary firing unit," Energy Conversation Management, vol. 5, pp. 296-308, 2011

[13] R. Mottaghianet, "SPRD steam power plant design," Power Plant Department of Matn Company, Tehran, Iran, 1999.

[14] J. M. Escosa and L. M. Romeo, "Optimizing $\mathrm{CO}_{2}$ avoided cost by means of repowering," Applied Energy, vol. 86, pp. 2351-2358, 2009.

[15] J. C. Backlund and J. Froeming, "Thermal and economical analysis of supplementary firing large combined cycle plants," Coen Company.

[16] N. R. Kumar, K. R. Krishna, and A. V. S. R. Raju, "Thermodynamic analysis of heat recovery steam generator in combined cycle power plant," Thermal Science, vol. 11, pp. 143-156, 2007.

[17] T. Sirinivas, A. Gupta, and B. V. Reddy, "Thermodynamic modeling and optimization of multi-pressure heat recovery steam generator in combined power cycle," Journal of SciInd, vol. 67, pp. 827-834, 2008.

[18] H. Sharifi, Heat Recovery Steam Generators, Tehran: Pendar Pars Publishers, 2011, ch. 3 .

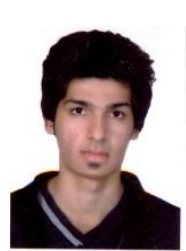

Vahid Rohani was born in Bojnurd, Iran in 1988 received his B.S. in 2010 and M.S. in 2013 in the Department of Mechanical Engineering at Shahid Rajaei Teacher Training University of Tehran. He is now working at Ministry of Education of Iran as a teacher. His current research interests are energy management and power plant designing.

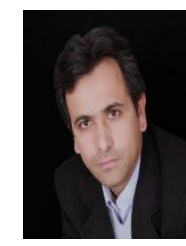

Mostafa Ahmadi was born in Bojnurd, Iran in 1976. received his B.S. in 2000 and M.S. in 2013 in the Department of Mechanical Engineering at Shahid Rajaei Teacher Training University of Tehran. He is now with Mechanics Department, Darol Fonoun Faculty, Bojnurd, Iran. His current research interests are enhancing efficiency of thermodynamic cycles, optimization of engine functional parameters and fluid mechanic. 